\title{
PENGALAMAN PEREMPUAN DALAM MEMPEROLEH HAK REPRODUKSI PADA MASA KEHAMILAN DAN NIFAS
}

\author{
Awatiful Azza $^{1,2 *}$, Achir Yani. S. Hamid ${ }^{3}$, Yati Afiyanti ${ }^{3}$ \\ 1. Fakultas Ilmu Kesehatan Universitas Muhammadiyah Jember, Jawa Timur 68121, Indonesia \\ 2. Program Studi Magister, Fakultas Ilmu Keperawatan Universitas Indonesia, Depok 16424, Indonesia \\ 3. Fakultas Ilmu Keperawatan Universitas Indonesia, Depok 16424, Indonesia \\ *Email: awatiful.azza@yahoo.com
}

\begin{abstract}
Abstrak
Studi fenomenologi ini dilakukan untuk menggali pengalaman perempuan dalam memperoleh hak reproduksinya selama masa kehamilan dan nifas. Data diperoleh melalui wawancara mendalam yang dilengkapi catatan lapangan terhadap delapan partisipan yang pernah hamil dan melahirkan di Desa A, Jember. Hasil penelitian ini melaporkan bahwa ada beberapa hak reproduksi yang belum diperoleh perempuan diantaranya hak menentukan pilihan pendamping hidup, hak membuat keputusan dalam menentukan jumlah dan jarak kelahiran anak, belum menikmati hubungan seks, serta belum mempunyai kebebasan berpikir dan membuat keputusan dalam mencari bantuan kesehatan. Penelitian ini juga mengungkapkan bahwa sepanjang masa kehamilannya perempuan banyak mendapat dukungan dari keluarga. Pelayanan preventif dan promotif hendaknya dapat memenuhi hak tersebut.
\end{abstract}

Kata kunci: hak reproduksi, kesehatan perempuan, kehamilan, nifas

\begin{abstract}
The women's experiences in obtaining their reproductive rights during pregnancy and postpartum period were explored in this phenomenological study. The data was gathered through in-depth interviews and field notes completed with eight participants who experienced pregnancy and postpartum in Arjasa, Jember District. The result revealed that the women did not obtain their rights namely choosing a spouse, decision making in having children and birth spacing, having an enjoyable sex relationship, and decision making in seeking health care. However, during pregnancy period they were supported from their relatives. Promotive and preventive health care should meet the women reproductive rights.
\end{abstract}

Keywords: reproductive rights, women health, pregnancy, postpartum period

\section{Pendahuluan}

Konferensi internasional tentang kependudukan dan pembangunan (International Conference on Population and Development-ICPD) di Kairo pada 1994 menempatkan kesehatan reproduksi sebagai perhatian khusus berskala global. Berkaitan dengan hal tersebut, pengelolaan masalah kependudukan dan pembangunan dilakukan melalui pendekatan terfokus pada kesehatan reproduksi serta upaya pemenuhan hak-hak reproduksi (Bambang, 2005).

Masalah hak perempuan merupakan kajian yang mendapat banyak perhatian. Fakta menunjukkan bahwa nasib kaum perempuan di negara Barat yang lebih maju pun tidak jauh berbeda dengan di negara lain. Kondisi ini pun ditemukan di negara Indonesia. Berbagai kasus pelanggaran hak reproduksi dapat dilihat dari banyaknya kasus perkosaan, termasuk dalam perkawinan, pemaksaan perjodohan, larangan aborsi, pelecehan seksual, penyiksaan, paksaan terhadap penggunaan alat kontrasepsi, tidak adanya akses mudah terhadap informasi tentang masalah kesehatan reproduksi, dan berbagai bentuk diskriminasi yang menomorduakan kedudukan perempuan (Hadi, 2007).

Swasono (2008) menyatakan persoalan hak reproduksi pada hakikatnya menyangkut hubungan jender atau jenis kelamin yang masih timpang. Selama perempuan masih berada dalam posisi subordinat, belum menjadi mitra sejajar laki-laki, terutama dalam kehidupan keluarga, selama itu pula perempuan akan tetap menanggung penderitaan dan kesengsaraan berkaitan dengan fungsi reproduksinya. Selain itu, pemahaman perempuan tentang hak reproduksi masih rendah dan seksualitas masih dianggap sebagai kodrat perempuan menjalankan kewajiban terhadap suami. 
Kondisi kesejahteraan perempuan tersebut tidak jauh berbeda di Jawa Timur. Di Kabupaten Jember, hak perempuan untuk memperoleh kesehatan reproduksi masih belum sesuai harapan. Hal tersebut disebabkan karena penerapan hak reproduksi masih sangat dipengaruhi faktor sosial dan budaya (Djunaidy, 2008). Data dari BKKBN (2005) menyebutkan tingginya angka kematian dan kesakitan ibu hamil, melahirkan, dan nifas akibat komplikasi sangat terkait dengan diskriminasi jender dalam masyarakat. Ini mengakibatkan terlantarnya hak perempuan bukan hanya pada saat hamil dan melahirkan tetapi sejak perempuan itu masih kecil dan remaja (BKKBN, 2005).

Untuk meningkatkan kesejahteraan perempuan pemerintah telah mengembangkan berbagai program. Akan tetapi, program tersebut belum berasal dari suara hati perempuan itu sendiri. Oleh karena itu, diperlukan penelitian yang menggunakan perspektif perempuan untuk menggambarkan permasalahan perempuan. Penelitian ini bertujuan mengeksplorasi pengalaman perempuan memperoleh hak reproduksi sepanjang masa kehamilan dan nifas.

\section{Metode}

Penelitian kualitatif ini menggunakan pendekatan fenomenologi yang berperspektif perempuan. Penelitian ini mengeksplorasi pengalaman perempuan sepanjang masa kehamilan dan nifas yang ada di Desa A, Jember. Pendekatan fenomenologi berperspektif perempuan mendefinisikan pengalaman dalam konteks yang spesifik dan kemudian secara induktif mengidentifikasi tema tentang pengalaman yang unik. Selain itu, pendekatan ini tidak hanya sekedar mementingkan metode riset, tetapi bagaimana hasil riset yang diperoleh dapat digunakan agar bisa menjawab berbagai kondisi kehidupan perempuan yang merugi akibat peran jendernya sehingga dapat menjalankan perannya sebagai ibu (Patton, 1992; Sadli, 1999).

Sebanyak delapan partisipan terlibat dalam penelitian, dipilih dengan metode purposeful sampling dengan kriteria; perempuan yang tinggal di wilayah kerja Puskesmas A, Jember, usia subur, sudah menikah dan mempunyai anak, mempunyai pengalaman hamil dan nifas mampu menceriterakannya dengan bahasa
Indonesia, bersedia menjadi partisipan dengan menandatangani informed concent.

Penelitian dilaksanakan di dusun $\mathrm{G}$ dan $\mathrm{K}$ wilayah kerja Puskesmas A, Jawa Timur. Waktu pelaksanaan penelitian sekitar tiga bulan. Data dikumpulkan melalui wawancara mendalam yang direkam dengan alat perekam digital dan catatan lapangan. Wawancara dilaksanakan sekitar 45 - 60 menit tiap satu kali pertemuan dengan partisipan. Pertanyaan pertama yang disampaikan ke partisipan untuk menggali perasaan partisipan dan selanjutnya digunakan berbagai teknik komunikasi untuk mendalami pernyataan dari partisipan.

Analisis data dilakukan secara bersamaan dengan pengumpulan data dengan metode Colaizzi. Interpretasi didapatkan dengan memasuki wawasan persepsi partisipan dengan cara melihat konteks transkrip dan catatan lapangan, kemudian melihat bagaimana mereka melewati suatu pengalaman kehidupan dan memperlihatkan serta menceritakan makna pengalaman informan (Basrowi \& Sukidin, 2008). Melalui transkrip wawancara, peneliti mengidentifikasi kata kunci dan kemudian dikelompokkan dalam kategori. Langkah berikutnya menyusun tema dari kategori dan kemudian dibuat deskripsi tema tersebut.

\section{Hasil}

Usia partisipan 18 - 35 tahun, agama Islam, dan suku Madura. Lima berdomisili di dusun Gumitir dan tiga partisipan di dusun Darsono. Pendidikan partisipan adalah dua tidak sekolah, dua tidak tamat SD, dua tamat SD, satu tidak tamat SMP/Tsanawiyah dan satu telah menyelesaikan studi SMEA. Semua partisipan dengan status ibu rumah tangga. Lima partisipan pernah melahirkan di rumah dan ditolong oleh dukun, satu orang melahirkan dibantu tenaga kesehatan, sedang dua orang pernah melahirkan di rumah sakit dengan bedah sesar. Lama perkawinan bervariasi antara dua tahun sampai 12 tahun.

Ada tujuh tema yang memaparkan pengalaman perempuan dalam memperoleh hak reproduksi, yaitu belum terpenuhinya hak menentukan pilihan pendamping hidup, membuat keputusan dalam menentukan jumlah 
anak dan jarak kelahiran anak, memperoleh perlakukan istimewa selama hamil dan nifas, belum menikmati hubungan seksual, kebutuhan memperoleh pelayanan kesehatan, kebebasan berpikir dan membuat keputusan dalam mencari bantuan kesehatan, harapan perempuan mendapatkan pelayanan kesehatan reproduksi.

\section{Belum Terpenuhinya Hak Menentukan Pilihan Pendamping Hidup}

Para partisipan mengatakan mereka belum memiliki hak untuk menentukan pendamping hidup. Mereka menikah atas dasar perjodohan orangtua di usia muda.

"Saya dinikahkan umur 18 tahun, suami juga tapi kalau orang sini rata-rata nikahnya ya... muda, ada yang masih 12 tahun sudah nikah dan punya anak, bu... padahal masih banyak yang belum lulus SD tapi ya ... gimana lagi...ya harus mau” (P3).

\section{Membuat keputusan dalam menentukan jumlah anak dan jarak kelahiran anak}

Perempuan juga belum dapat menentukan sendiri kapan dan berapa anak yang diinginkan. Keputusan tersebut diambil terutama oleh suami dan orangtua. Salah satu pernyataan berikut merupakan contoh dominasi orangtua dan suami dalam memutuskan jumlah dan jarak kelahiran anak.

"Orangtua dan suami pingin saya segera punya anak lagi. Saat itu saya ya gimana ya.. mau saja bu, apalagi kan sudah menjadi kewajiban istri bu kalau suaminya ingin punya anak ya... mau saja..." (P1).

"Suami saya yang nyuruh ikut KB, takut kebobolan. Anak saya kan masih kecil bu” (P6).

\section{Memperoleh Perlakukan Istimewa selama Hamil dan Nifas}

Beberapa partisipan lain memperoleh hak reproduksi yaitu memperoleh perlakuan "istimewa" selama hamil dan nifas yang banyak memperoleh dukungan termasuk informasi dan keuangan dari keluarga maupun petugas kesehatan. Berikut ungkapan para partisipan tersebut.

"Saya kan di rumah dengan ibu saya jadi yang nasehati dan mbantu-bantu ya....ibu saya, saya masih belum tahu bu cara-caranya kalau orang ngandung itu bagaimana..." (P6).

“...terutama ibu mertua sangat perhatian, saya banyak dibantu dalam melakukan pekerjaan rumah, jadi saya ndak merasa berat selama hamil Bu...”(P8).

\section{Belum Menikmati Hubungan Seksual}

Pengalaman yang diungkapkan oleh partisipan menunjukkan bahwa mereka belum memperoleh haknya untuk menikmati hubungan seksual. Sering kali mereka melakukan karena hanya memenuhi kebutuhan suami bukan atas keinginan sendiri. Mereka tidak punya keberanian untuk menolak suami. Ada juga yang melakukan hubungan seksual karena berpendapat bahwa hubungan seksual selama kehamilan dapat memperlancar proses persalinan.

"Kepercayaan orang sini kalau hubungan suami istri selama hamil itu bisa menambah tubuh bayi bu...ya bayinya ditambah kupingnya, maripatnya...biar normal bu, makanya saya ndak berani nolak bu takut anaknya ndak normal..." (P1).

"ya kata orang tua bu, katanya kalau hubungan sebelum melahirkan bisa untuk buka jalan”(P8).

"ya...ndak apa-apa ya... saya ndak berani nolak bu, itu kan sudah kewajiban sebagai istri.... apalagi kalau orang hamil katanya biar anaknya ndak kurang harus hubungan bu..." (P6).

\section{Kebutuhan Memperoleh Pelayanan Kesehatan}

Tema yang terungkap dari tujuan ini adalah perempuan telah memperoleh pelayanan kesehatan dari tenaga kesehatan maupun non tenaga kesehatan. Beberapa perempuan memperoleh pelayanan kesehatan dari tenaga kesehatan, seperti pernyataan dari partisipan ini:

"Ya...saya saat hamil dan setelah melahirkan periksa di Puskesmas, bu...” (P7).

Namun demikian, ada juga partisipan yang mencari pelayanan bukan dari tenaga kesehatan. Berikut pernyataan partisipan:

"Biasanya masyarakat sini kalau ingin tahu hamil atau ndak ya cuma dilihatkan ke dukun, 
bu. Dukunnya tahu bu, kalau hamil atau ndak, dukunnya kan pengalaman...." (P2).

\section{Kebebasan Berpikir dan Membuat Keputusan dalam Mencari Bantuan Kesehatan}

Perempuan sangat tergantung pada suami saat harus memutuskan untuk periksa ke Polindes. Perempuan akan meminta diantarkan oleh suami karena jarak Polindes yang cukup jauh seperti pernyataan berikut:

"Ya... saya yang minta ke suami, bu.. yang pertama saya diantar naik sepeda dengan suami, bu, terus periksa yang lainnya saya naik ojek sendiri, mahal bu, ojeknya. Tapi kalau di dukun saya jalan sendiri, agak dekat kok, bu..." (P5).

\section{Harapan Perempuan Mendapatkan Pelayanan Kesehatan Reproduksi}

Perempuan sangat mengharapkan bahwa pelayanan kesehatan reproduksi perlu disosialisasikan ke pelosok desa, seperti pernyataannya berikut ini:

"Ya.. sudah bu, cuma kalau untuk masyarakat di desa kurang sosialisasinya jadi masih perlu di-tingkatkan, sebenarnya kalau posyandu masyarakat banyak yang datang bu, ya mungkin di atas harus ada bidan atau petugas kesehatan lagi biar masyarakat yang ada di pelosok dapat menikmati pelayanan selama hamil bu..." (P8).

\section{Pembahasan}

Hak reproduksi merupakan hak dasar dari setiap pasangan yang dijamin dalam kesepakatan internasional. Ada 12 hak reproduksi yang ditetapkan dari hasil konferensi di Kairo pada tahun 1994. Hak reproduksi ini dipandang penting artinya bagi setiap individu demi terwujudnya kesehatan indi vidu secara utuh, baik kesehatan jasmani maupun rohani sesuai dengan norma hidup sehat (Bambang, 2005).

Kondisi kesejahteraan perempuan dalam memperoleh hak reproduksi juga dikaji pada masyarakat Jember. Kehidupan masyarakat Jember secara sosial budaya masih sangat kental dipengaruhi oleh budaya Madura. Meskipun Jember termasuk kota pendidikan, namun masih banyak orangtua yang menikahkan anaknya pada usia dini. Hal tersebut menunjuk- kan bahwa masih banyak perempuan yang belum mendapatkan haknya untuk menentukan pilihan pendamping hidup. Pada masyarakat urban Madura yang ada di Jember, orang tua banyak berkontribusi terhadap perempuan dalam membuat keputusan tentang pernikahannya. Perempuan tidak dapat menolak saat orangtuanya menjodohkan. Beberapa alasan dikemukakan orangtua untuk menikahkan anak mereka pada usia muda, diantaranya karena takut kalau tidak laku, mengikuti kebiasaan yang ada di masyarakat, dan untuk melanjutkan keturunan.

Hasil penelitian Indarsih, (1999 dalam Hamdanah 2005) yang dilakukan di Jember dan Situbondo menunjukkan sebagian besar (72\%) perempuan dinikahkan oleh orangtuanya pada usia yang sangat muda. Temuan ini didukung penelitian Savitri (2003), bahwa alasan orangtua untuk menikahkan anak pada usia dini yaitu takut kalau dianggap tidak laku, selain faktor kemiskinan sebagai alasan lainnya. Ketaatan perempuan Madura urban terhadap orangtua merupakan kultur atau budaya yang mereka pegang teguh. Hal tersebut membuat perempuan tidak berani menolak keinginan orangtua karena mereka takut akan dianggap sebagai anak yang durhaka. Dampak pernikahan dini ditinjau dari segi kependudukan adalah laju pertumbuhan penduduk menjadi cepat karena makin pendeknya interval antar generasi dengan makin besarnya tingkat kesuburan (Zakiah, 2000).

Penelitian ini menunjukkan bahwa perempuan belum mendapatkan haknya dalam membuat keputusan untuk menentukan dan mengatur jumlah anak. Posisi perempuan merupakan salah satu penyebab ketidakmampuan perempuan dalam mengambil keputusan mengenai jumlah anak yang diinginkan. Penelitian yang dilakukan oleh Asmi (2004), yang mengungkapkan walaupun perempuan dalam rumah tangga mempunyai peran besar dalam bidang ekonomi, tetapi mereka tidak mampu mengambil keputusan yang berkaitan dengan hak reproduksinya terutama dalam menentukan jumlah anak. Temuan ini juga membuktikan bahwa kebenaran analisis yang ditawarkan oleh feminis sosialis, yang menyatakan bahwa perempuan tetap tersubordinasi sekalipun mempunyai peran besar pada sumber ekonomi sepanjang budaya patriarki masih dominan (Swasono, 2008). 
Hasil penelitian ini mengungkapkan bahwa perempuan banyak mendapat dukungan sepanjang kehamilan dan melahirkan. Kekerabatan yang sangat kental pada budaya Madura urban membuat perempuan selama kehamilannya banyak mendapat dukungan baik dari lingkungan maupun keluarga. Kondisi demikian membuat perempuan dapat melalui masa kehamilan tersebut dengan tenang. Menurut Mercer (1999), bahwa dukungan emosi dari pasangan merupakan faktor penting dalam mencapai keberhasilan tugas perkembangan ibu. Perempuan selama hamil akan banyak mengalami perkembangan baik fisik maupun emosi, sehingga membutuhkan dukungan dari orang yang ada disekitarnya.

Faktor lain yang dapat menyebabkan perempuan belum mendapatkan hak reproduksinya sepanjang masa kehamilan, diantaranya mitos yang berhubungan dengan seks selama hamil. Mitos yang berkembang bahwa perempuan yang hamil harus melakukan hubungan seks agar bayi yang dilahirkan tidak mengalami cacat. Hal ini menyebabkan perempuan tidak berani menolak hubungan seks walaupun kondisi perempuan sedang tidak nyaman. Padahal Schaffir (2006) mengungkapkan tidak ada perbedaan bayi yang dilahirkan dari wanita yang aktif melakukan aktifitas seks dan yang tidak selama kehamilannya.

Menurut Pangkahila (2008) bahwa hubungan seksual menyangkut kepentingan dua orang dalam satu pasangan. Oleh karena itu, hubungan seksual seharusnya tidak hanya untuk kepentingan suami namun juga disesuaikan dengan keadaan perempuan yang sedang mengalami kehamilan. Pengambilan keputusan mengandung arti pemilihan alternatif terbaik dari sejumlah alternatif yang tersedia. Teori-teori pengambilan keputusan bersangkut paut dengan masalah bagaimana pilihan akan dibuat (Swansburg, 2000).

Banyak faktor yang menentukan seseorang dalam membuat keputusan, baik faktor internal maupun eksternal.Perempuan dalammembuat keputusan tentang pelayanan kesehatan selama hamil dan nifas sangat tergantung pada biaya yang harus dikeluarkan, jarak pelayanan, dan kebiasaan di masyarakat. Hal tersebut menyebabkan masih banyaknya perempuan yang membuat keputusan untuk melahirkan di dukun.
Kemampuan ibu dalam mencari bantuan pelayanan kesehatan akan meningkatkan status ibu dalam menjalani kehamilan dan persalinannya. Dukun selalu menjadi pilihan karena sangat terjangkau masyarakat baik segi biaya maupun jarak (Song, 2009). Akan tetapi, penelitian Karsanto (2007) menyatakan sebaliknya, bahwa kontribusi perempuan dalam perekonomian keluarga dapat meningkatkan posisi tawar istri dalam pengambilan keputusan mengenai pelayanan kesehatan. Perbedaan temuan tersebut disebabkan perempuan dalam membuat keputusan tentang layanan kesehatan banyak dipengaruhi kondisi lingkungan, sosial, budaya, serta ekonomi (Swansburg, 2000).

Mengenai pelayanan kesehatan yang didapatkan selama kehamilan dan nifas, partisipan merasa sudah cukup baik. Respon tersebut banyak dipengaruhi anggapan umum tentang pelayanan kesehatan, yaitu apabila sudah diperiksa bagian perut dan diberi nasihat mengenai kehamilan dan nifas, mereka mengatakan pelayanan tersebut sudah cukup baik. Apalagijika yang menyampaikan informasi kesehatan tersebut sabar, telaten dan berpengaruh. Partisipan juga berharap untuk mendapat kemudahan akses terhadap pelayanan kesehatan reproduksi. Kondisi ini sama dengan yang dikemukakan Purdy (2006), pelayanan kesehatan perempuan selama kehamilan hingga nifas masih kurang diakses karena keterbatasan ekonomi.

Pengalaman perempuan yang mempunyai kaitan dengan kesehatan reproduksi akan lebih bervariasi, apabila latar belakang partisipan lebih luas. Latar belakang partisipan yang bervariasi akan memperkaya data yang diperoleh.

\section{Kesimpulan}

Pengalaman perempuan dalam memperoleh hak reproduksi sangat bervariasi, ada hak yang sudah diperoleh sepanjang masa kehamilan dan nifas, tetapi ada juga hak yang belum terpenuhi. Kondisi tersebut tentunya ada dampaknya pada perempuan selama menjalani kehamilan dan nifas. Masih tingginya perempuan yang memilih bantuan dukun juga merupakan salah satu bentuk tidak terpenuhinya hak reproduksi perempuan dalam mendapatkan pelayanan kesehatan secara profesional. 
Perlu dikembangkannya bentuk tanggung jawab suami dalam menjaga kesehatan reproduksi istrinya melalui edukasi terpadu dari berbagai pihak, yaitu dari petugas kesehatan, ulama, dan pemuka masyarakat tentang pentingnya kebersamaan dan kerjasama dalam menjaga kesehatan perempuan, termasuk kesehatan reproduksinya. Sosialisasi dan perhatian tentang hak reproduksi terhadap anak perempuan maupun orangtua juga perlu ditingkat menentukan kan sehingga perkawinan dapat ditunda hingga cukup usia. Penelitian selanjutnya perlu dilakukan untuk mengeksplorasi pengalaman laki-laki, pasangan, atau tenaga kesehatan dalam membantu perempuan untuk memperoleh hak reproduksinya (AR, YN, INR).

\section{Referensi}

Asmi. (2004). Hak reproduksi perempuan pada masyarakat matrilinial Minangkabau di pedesaan Provinsi Sumatra Barat (Studi kasus perempuan di desa Bulakan Tinggi, Kecamatan Perwakilan Situjuh, Kabupaten Lima Puluh Kota, Provinsi Sumatra Barat). (Tesis, tidak diterbitkan). Universitas Indonesia, Jakarta.

Bambang, E. (2005). Dua belas hak reproduksi perempuan yang dijamin dalam perjanjian international. Diperoleh dari http://www.jurnalis perempuan.com.

Basrowi, \& Sukidin. (2002). Metode penelitian kualitatif perspektif mikro. Surabaya: Insan Cendekia.

Basrowi, \& Suwandi. (2008). Memahami penelitian kualitatif. Jakarta: Rineka Cipta.

BKKBN. (2005). Hak reproduksi perempuan terabaikan, UU kesehatan perlu disempurnakan. Jakarta: BKKBN.

Departemen Kesehatan RI. (2002). Upaya menurunkan angka kematian ibu. Jakarta: Departemen Kesehatan.

Djunaidy. (2008). Angka kematian ibu dan bayi di Jember tinggi. Diperoleh dari http://www.tempo interactive.com.

Hadi, T. (2007). Hak reproduksi dan ketidakadilan gender. Diperoleh dari http://www.pikiranrakyat.com.
Hamdanah. (2005). Musim kawin di musim kemarau: Studi atas pandangan ulama perempuan Jember tentang hak-hak reproduksi perempuan. Yogyakarta: Bigraf.

Karsanto. (2007). Peran istri yang bekerja sebagai pedagang dalam pengambilan keputusan keluarga (studi kasus) (Tesis, tidak dipublikasikan). Universitas Airlangga, Surabaya.

Mercer, R.T. (1999). Parent infant attachment. Women's health: Childbearing, 2, 17-42.

Song, K. (2009). Maternity care, a major segment of health industri, must be over-hauled for health care reform to succeed. Diperoleh dari http://www.childbirthconnection. org.

Swasono, M.F. (2008). Partisipasi laki-laki dalam kesehatan reproduksi. Diperoleh dari http:// www.menegpp.go.id.

Pangkahila, W. (2008). Mitos seks meliputi kehamilan. Diperoleh dari http://www.mail-archive.com.

Patton, M. Q. (1992). Qualitative evaluation and research methods (2nd Ed.). Thousand Oaks: Sage Publications, Inc.

Purdy, L. (2006). Women's reproductive autonomy: Medicalisation and beyond. Journal of Medical Ethics.; 32; 287-291.

Sadli, S. (1999). Metodologi penelitian berperspektif perempuan dalam riset social. Jakarta: Program studi kajian wanita pasca sarjana Universitas Indonesia.

Savitri. (2003). Memasyarakatkan kesehatan reproduksi wanita (Penelitian, tidak dipublikasikan).Universitas Sumatra Utara, Medan.

Schaffir, J. (2006). Sex in pregnancy. Issue of obstetrics and gynecology publication. Ohio: University Colombus.

Swansburg, R. (2000). Introductory management and leadership for clinic nurse. (Samba, penerjemah). Jakarta: EGC.

Zakiyah. (2000). Memposisikan kodrat, perempuan, dan perubahan dalam perspektif Islam. Bandung: Mizan. 